\title{
Carcinoma Originating from Aberrant Breast Tissue: Case Report and Review of the Literature
}

\author{
L Boulaamane $^{1 *}$, B Khanouss ${ }^{2}$, B El Ghissassi ${ }^{1}$, H M rabti and H Errihani ${ }^{1}$
}

${ }^{1}$ Department of Medical Oncology - National Institute of Oncology, Rabat, Morocco

${ }^{2}$ Department of Pathology - National Institute of Oncology, Rabat, Morocco

\begin{abstract}
Aberrant mammary tumors are ectopic tumors, which represent $0.3 \%$ of all breast cancers. These tumors often occur close to normal breast, near the sternum, epigastrum, subclavicular, and axillary area which is the most common. We report a 76-year-old woman, without history of disease, presenting one year ago, a nodule located between breasts, increasing rapidly in size. Clinical examination found an inflammatory mid-chest mass, measuring $15 \mathrm{~cm}$ of diameter, located between breasts. Axillary lymph nodes were not enlarged, and no masses were palpable in the breasts. Biopsy with immuno-histochemical study showed invasive ductal breast origin carcinoma, with positive CK7 antigen, negative CK20 antigen, positive hormone receptors and negative HER2/neu oncoprotein. Bilateral mammography showed invasion the left breast. Computed tomography showed bilateral pulmonary metastasis. The patient received 5 courses of palliative chemotherapy based on Anthracycline, with more than $80 \%$ of partial response obtained. The patient died from sepsis before receiving the sixth course of treatment. Aberrant mammary tumors originated from accessory fragments of breast tissue beyond mammary gland. These aberrant breast tissues can grow and cancerize, with or without involvement of the two normal mammary glands. In this case report, both normal breasts are free from any adjacent tumor proliferation, and it is the first case in literature, reporting a considerable size of aberrant breast tissue.
\end{abstract}

Keywords: Aberrant mammary tumors; Carcinoma of ectopic breast tissue; Accessory fragments of breast tissue

\section{Introduction}

Ectopic Breast Tissue (EBT) refers to supernumerary and aberrant breast tissue [1,2]. A classification of EBT has been offered by Copeland and Geschickter, in which accessory nipple formation, areolar formation, or both, with or without glandular breast, is termed supernumerary breast, as opposed to aberrant breast, referring to ectopic breast tissue without a nipple or areolar complex [1]. EBT without the presence of a nipple located beyond the periphery of the gland is defined as aberrant breast tissue and is frequently misdiagnosed as a subcutaneous lesion. EBT results from a failure of regression of the mammary ridges during embryogenesis [3]. It can be present anywhere along the milk line, from the axilla to the inguinal region [4-11]. The incidence of ectopic accessory breast is uncertain, but it is generally accepted to be found in $1-2 \%$ of humans $[12,13]$. EBT is subject to all of the physiological and pathological changes of the normal breast, including carcinoma [14], although carcinoma of aberrant breast tissue is rare $[15,16]$.

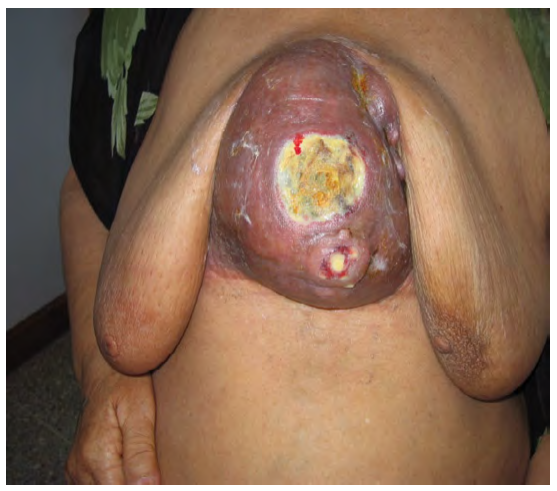

Picture 1: tumor front characteristic's.

\section{Case Report}

We report a clinical case of a 76-year-old post menopausal woman. Her past medical history was significant only for long-standing hypertension, not compromising cardiac function. She had not prior breast complaints or breast surgeries and her family history was negative for breast or ovarian cancer in a primary relative.

She had discovered a small nodule of $2 \mathrm{~cm}$ of diameter, one year earlier located in pre-sternal area, which had maintained a stable clinical appearance, without palpable nodule in both breasts. No treatment measure was taken initially. The mass had been increasing rapidly in size; 3 months before therapeutic management.

Clinical examination revealed a mid-chest, firm, fixed, burgeoning and inflammatory mass, measuring $15 \mathrm{~cm}$ of diameter in the length, $11 \mathrm{~cm}$ in width and $7 \mathrm{~cm}$ in height, located between breasts (pictures $1,2)$. No masses were found in both breasts and there was no palpable axillary or sus-clavicular lymphadenopathy.

Ultrasonogram could not be done because of the inflammatory character of the mass, bleeding and discharge of pus clinically disseminated in the tumor. The patient underwent a biopsy of this mass. Histopathological and immuno-histochemical studies showed invasive ductal breast origin carcinoma, with positive CK7 antigen, negative

*Corresponding author: L Boulaamane, Department of Medical Oncology - National Institute of Oncology, Rabat, Morocco, E-mail: lamya_boulaamane@hotmail.fr

Received October 22, 2013; Accepted November 21, 2013; Published December 19, 2013

Citation: Boulaamane L, Khanouss B, El Ghissassi B, rabti HM, Errihani H (2013) Carcinoma Originating from Aberrant Breast Tissue: Case Report and Review of the Literature. J Integr Oncol 3: 110. doi:10.4172/2329-6771.1000110

Copyright: $(2013$ Boulaamane L, et al. This is an open-access article distributed under the terms of the Creative Commons Attribution License, which permits unrestricted use, distribution, and reproduction in any medium, provided the original author and source are credited. 
Citation: Boulaamane L, Khanouss B, El Ghissassi B, rabti HM, Errihani H (2013) Carcinoma Originating from Aberrant Breast Tissue: Case Report and Review of the Literature. J Integr Oncol 3: 110. doi:10.4172/2329-6771.1000110

Page 2 of 4

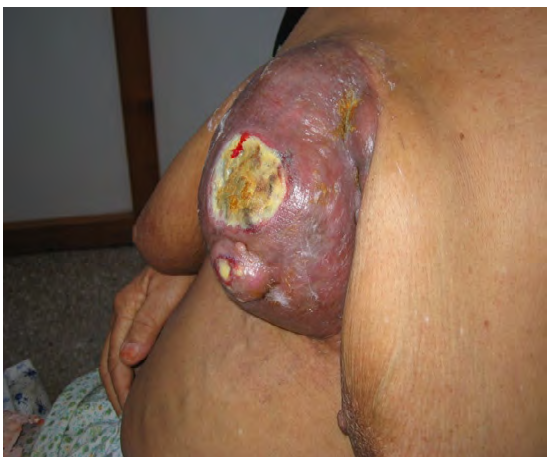

Picture 2: tumor profile characteristic's.

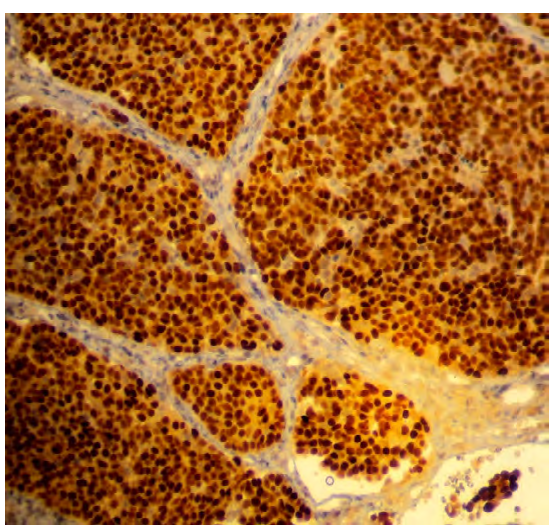

Figure 1: Microphotography showing positivity for estrogenic receptors.

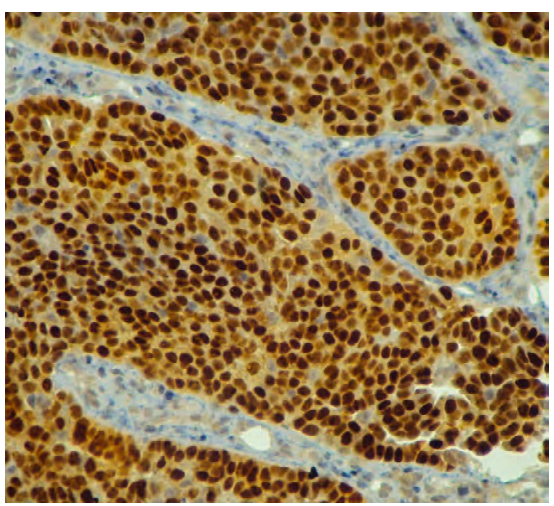

Figure 2: Microphotography showing positivity for progesteronic receptors.

CK20 antigen, positive both estrogene and progesterone receptors (figures 1,2) and negative HER2/neu oncoprotein expression.

Bilateral standard mammograms and additional axillary projections showed invasion of the upper inner quadrant of the left breast by described lesion, and negative axillary lymph node involvement. Mass development in the pre-sternal area and the absence of clinically evident involvement of both breasts initially, evoked aberrant origin of the primary mammary parenchyma.

Given the locally advanced character of the mass and suspected secondary pulmonary lesions in standard chest X-ray, Computed Tomography (CT scan) was performed and confirmed bilateral pulmonary metastasis. Bone scan was negative of any involvement. Breast magnetic resonance imaging was not performed given metastatic stage of the tumor.

Neo-adjuvant chemotherapy to surgical excision was not considered because of presence of disseminated bilateral pulmonary metastasis. Given good performance status, the patient was then treated with reduced dose of chemotherapy protocol based on Anthracycline. Clinical tumor response was evident and partial radiological response greater than $80 \%$ was confirmed in CT scan after 3 courses of chemotherapy (picture 3,4 ).

The patient was hospitalized for febrile neutropenia after the fourth cycle which was well managed with antibiotics treatment. Granulocyte colony-stimulating factors were therefore indicated subsequently to cycles of chemotherapy, but injections were not received. The patient had presented then sepsis related to second episode of bacteriological undocumented febrile neutropenia. Clinically, tumor response was maintained and the patient died 7 months after diagnosis.

\section{Discussion}

During gestation, EBT is formed if the mammary ridge does not

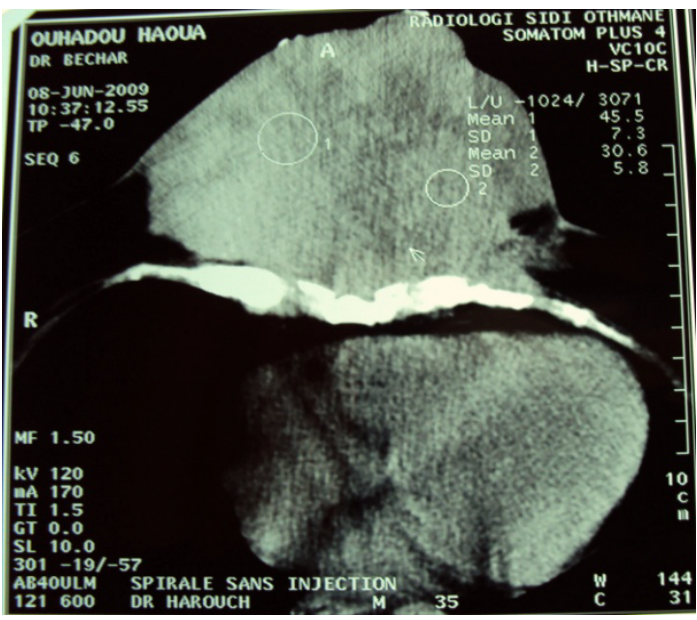

Picture 3: CT scan before treatment.

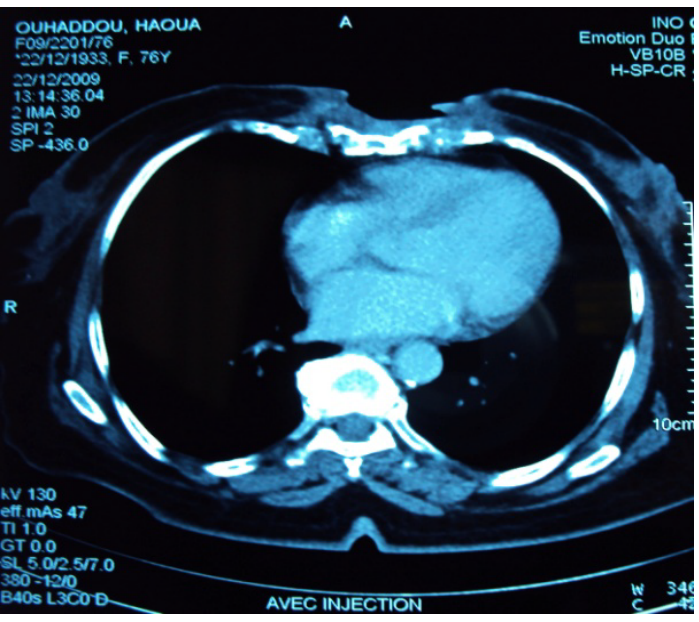

Picture 4: CT scan after 3 courses of chemotherapy. 
disappear normally. Failure of regression of the mammary ridge results on EBT with varying degrees of clinical expression $[3,7,10,17]$.

Accessory breast tissue may take several forms and has been classified by Kajava as follows: complete breast with nipple, areola, and glandular tissue; supernumerary breast without areola but with nipple and glandular tissue; supernumerary breast without nipple but with areola and glandular tissue; aberrant glandular tissue without nipple or areola; pseudo-mamma with nipple and areola but without glandular tissue; polythelia; polythelia areolaris; polythelia pilosa $[4,18,19]$. Polymastia is the term used to describe the presence of more than 2 breasts in human subjects; it is synonymous with ectopic, accessory, or supernumerary breast $[7,10,20]$.

EBT includes supernumerary breasts and aberrant breast tissue $[1,2]$. Supernumerary breasts are most commonly present along the embryological milk-line, running from axilla to groin, but may also occur in other sites, including cheek, neck, shoulder, midline of chest or abdomen, flank, hip, thigh, and buttock. Aberrant breasts, in contrast, are found in proximity to the normal breast and consist of accessory fragments of breast tissue beyond the periphery of the gland. It may occur in the axillary, sternal, infraclavicular, or epigastric regions $[12,13]$, among which the axillary site is the most common $[2,13,21]$.

EBT can develop with any disease that affects the normal breast, including breast carcinoma [14,22]. They commonly respond to the hormonal stimulations of menses or pregnancy in terms of engorgement and discomfort [13].

Different varieties of breast cancer have been found in ectopic breasts, such as fibroadenomas, fibrocystic changes, atypical ductal hyperplasia, phyllodes tumors, mastitis and abscesses [5,6,8,22-27]. All benign or malignant tumors that occur in normal breast tissue may also arise in EBT. Ductal carcinoma is the most histological subtype reported. Other types of breast cancer have also been described such as medullary, papillary, and lobular carcinomas $[5,6,8,18,23,28]$ (table).

Carcinoma of EBT is approximately $0.3 \%$ of all breast cancers [15], though only Badejo reported a $14 \%$ incidence in a series of 22 breast carcinomas [29]. True incidence of this type of breast cancer is not yet clear. It relates to the uncertainty about the incidence of benign ectopic axillary breasts and the disparate methods of reporting. De Cholnoky [27], for instance, reported a 3.8\% incidence of carcinoma (actually only one case) in a series of 28 operated cases of ectopic axillary breasts. By contrast, Chiari [15] found only 3 ectopic occurrences in a series of 918 cases of breast cancer for an approximate $0.3 \%$ incidence of all breast cancers. Cheong et al. [16] noted that only 4 cases $(0.28 \%)$ of axillary breast cancer were found among a total of 1,430 cases of operated breast cancer during 10 years.

Most carcinomas of aberrant breast tissue occur near the axilla $[2,23,30]$. Evans and Guyton [23], in a summary of reported cases of

\begin{tabular}{|l|c|c|c|c|}
\hline Gender & Age & $\begin{array}{c}\text { Clinical } \\
\text { presentation }\end{array}$ & $\begin{array}{c}\text { Histopathological } \\
\text { examination }\end{array}$ & $\begin{array}{c}\text { Treatment } \\
\text { received }\end{array}$ \\
\hline Woman (5) & 46 years & $\begin{array}{c}\text { Right axillary firm } \\
\text { mass with fluid } \\
\text { secretion }\end{array}$ & $\begin{array}{c}\text { Invasive (juvenile) } \\
\text { secretory } \\
\text { carcinoma }\end{array}$ & $\begin{array}{c}\text { Right } \\
\text { lymphadenectomy } \\
\text { with adjuvant } \\
\text { chemotherapy }\end{array}$ \\
\hline Woman (6) & 47 years & $\begin{array}{c}\text { Ulcerated nodule } \\
\text { in the right labia } \\
\text { minor of the vulva } \\
\text { with foul-smelling } \\
\text { discharge }\end{array}$ & $\begin{array}{c}\text { Mucinous } \\
\text { adenocarcinoma }\end{array}$ & $\begin{array}{c}\text { Anterior radical } \\
\text { vulvectomy }\end{array}$ \\
\hline
\end{tabular}

Table 1: Other location of ectopic breast tissue. ectopic breast cancer, noted that 64 of 90 cases occurred in the axilla while 26 occurred in the extraaxillary sites with 15 in the sternal area, 9 in the subclavian region, and 2 in the labia. Copeland and Geschickter noted 7 of 9 cases in the axilla and 2 in the sternal region [1]. Chiari collected 57 cases of carcinoma of aberrant breast tissue from the literature and added 3 of his own. Of the 60 cases, 43 occurred in the axilla, 6 in the infraclavicular region, 6 in the sternal aera, and 5 in the epigastrium, close to the xiphisternal junction [15].

To the best of our knowledge, this is the first case report of carcinoma of aberrant breast tissue occurring in the extra-axillary site, particularly in the sternal region, and measuring a considerable size of $15 \mathrm{~cm}$ of diameter, with inflammatory character.

Carcinoma arising from EBT can be diagnosed in the same manner as regular breast carcinoma using clinical examination, ultrasonography, rarely mammography, core-needle biopsy, fine-needle aspiration biopsy, or gross excision and subsequent pathological diagnosis [20,31,32]. Special and appropriate evaluation method of axillary breast tissue is the physical examination and axillary ultrasonography. Standard mammograms do not usually show EBT because of its location [33].

There are no published series that evaluate the use of chemotherapy or radiation therapy in the treatment of EBT; only individual patients case reports exist.

For located stage, the best treatment option is surgical excision of primary tumor with lymph node dissection followed by radiation therapy and chemotherapy or endocrine therapy [4], if no concomitant tumor in the breasts is associated.

Disseminated EBT is extremely rare, and treatment is probably similar to metastasis normal breast carcinoma.

Regarding the rareness of this disease and the limited follow-up data, no prognostic conclusions are available, but EBT seems to have a poorer prognosis than cancer in normal breast parenchyma [4,34]. The prognosis is thought to be poor because early diagnosis is difficult.

\section{Conclusion}

In summary, we can conclude that subcutaneous nodules of uncertain origin around the periphery of the breast, especially in the axilla and along the sternum, should always be viewed with suspicion for breast carcinoma of aberrant breast tissue.

Careful follow-up of these patients is essential, especially because the natural history of this rare entity is not well defined.

\section{References}

1. Copeland MM, Geschickter CF (1950) Diagnosis and treatment of premalignant lesions of the breast. Surg Clin North Am 30: 1717-1741.

2. Marshall MB, Moynihan JJ, Frost A, Evans SRT (1994) Ectopic breast cancer: case report and literature review. Surg Oncol 3: 295-304.

3. Langman J (1985) Medical embryology. (5thedn), Williams and Wilkins, Baltimore, United States.

4. Fracchioli S, Puopolo M, De La Longrais IA, Scozzafava M, Bogliatto $F$, et al. (2006) Primary "breast-like" cancer of the vulva: a case report and critical review of the literature. Int J Gynecol Cancer 16: 423-428.

5. Shin SJ, Sheikh FS, Allenby PA, Rosen PP (2001) Invasive secretory (juvenile) carcinoma arising in ectopic breast tissue of the axilla. Arch pathol Lab Med 125: $1372-1374$

6. Chung-Park M, Zheng Liu C, Giampoli EJ, Emery JD, Shalodi A (2002) Mucinous adenocarcinoma of ectopic breast tissue of the vulva. Arch Patho Lab Med 126: 1216-1218. 
Citation: Boulaamane L, Khanouss B, El Ghissassi B, rabti HM, Errihani H (2013) Carcinoma Originating from Aberrant Breast Tissue: Case Report and Review of the Literature. J Integr Oncol 3: 110. doi:10.4172/2329-6771.1000110

Page 4 of 4

7. Burdick AE, Thomas KA, Welsh E (2003) Axillary polymastia. J Am Acad Dermatol 49: 1154-1156.

8. Yin C, Chapman J, Tawfik O (2003) Invasive mucinous (colloid) adenocarcinoma of ectopic breast tissue in the vulva: A case report. Breast J 9: 113-115.

9. Giron GI, Friedman I, Feldman S (2004) Lobular carcinoma in ectopic axillary breast tissue. Am Surg 70: 312-315

10. Alghamdi $H$, Abdelhadi M (2005) Accessory breasts: When to excise? Breast J 11: 155-157.

11. Paksoy N (2007) Ectopic lesions as potential pitfalls in fine needle aspiration cytology: a report of 3 cases derived from the thyroid, endometrium and breast. Acta Cytol 51: 222-226.

12. Cogswell HD, Czerny EW (1961) Carcinoma of aberrant breast of the axilla Am J Surg 27: 388-390.

13. Smith GMR, Greening WP (1972) Carcinoma of aberrant breast tissue: a report of 3 cases. Br J Surg 59: 89-90.

14. Yerra L, Karunad AB, Votaw ML (1997) Primary breast cancer in aberrant breast tissue in the axilla. South Med J 90: 661-662.

15. Chiari HH (1958) Cancer in aberrant breast tissue. Bruns Beitr Klin Chir 197 307-314.

16. Cheong JH, Lee BC, Lee KS (1999) Carcinoma of the axillary breast. Yonse Med J 40: 290-293.

17. Bakker JR, Sataloff DM, Haupt HM (2005) Breast cancer presenting in aberrant axillary breast tissue. Commun Oncol 2: 117-120.

18. Gutermuth J, Audring H, Voit C, Haas N (2006) Primary carcinoma of ectopic axillary breast tissue. J Eur Acad Dermatol Venereol 20: 217-221.

19. Kajava $Y(1915)$ The proportions of supernumerary nipples in the Finnish population. Duodecim 31: 143-170.

20. Silverberg MA, Rahman MZ (2003) Axillary breast tissue mistaken for suppurative hidradenitis: an avoidable error. J Emerg Med 25: 51-55.

21. Velanovich V (1995) Ectopic breast tissue, supernumerary breasts, and supernumerary nipples. South Med J 88: 903-906.
22. Lesavoy MA, Gomez-Garcia A, Nejdl R, Yospur G, Syiau TJ, et al. (1995) Axillary breast tissue: clinical presentation and surgical treatment. Ann Plast Surg 35: 356-360.

23. Evans DM, Guyton DP (1995) Carcinoma of the axillary breast. J Surg Onco 59: 190-195.

24. Saleh HA, Klein LH (1990) Cystosarcoma phyllodes arising synchronously in right breast and bilateral axillary ectopic breast tissue. Arch Pathol Lab Med 114: 624-626.

25. Oshida K, Miyauchi M, Yamamoto N, Takeuchi T, Suzuki M, et al. (2003) Phyllodes tumor arising in ectopic breast tissue of the axilla. Breast Cancer 10: 82-84.

26. Baykal C, Tulunay G, Usubutun A, Küçükali T, Ozer S, et al. (2004) Fibrocystic disease of vulvar ectopic breast tissue. Case report and review of the literature. Gynecol Obstet Invest 58: 151-154.

27. De Cholnoky T (1951) Accessory breast tissue in the axilla. N Y State J Med 51: 2245-2248.

28. Christey GR, Civil ID (1998) Invasive lobular carcinoma in an axillary breast. Aust N Z J Surg 68: 305-306.

29. Badejo OA (1984) Fungating accessory breast carcinoma in Nigerian women. Trop Geogr Med 36: 45-49.

30. Nakao A, Saito S, Inoue F, Notohara K, Tanaka N (1998) Ectopic breast cancer: a case report and review of the Japanese literature. Anticancer Res 18: 3737 3740 .

31. Ganaraj A, Petrek JA (2002) Diagnosis and treatment of cancer arising in ectopic breast tissue. Clin Rev 58: 566-570.

32. Rho JY, Juhng SK, Yoon KJ (2001) Carcinoma originating from aberrant breas tissue of the right upper anterior chest wall : a case report. J Korean Med Sci 16: 519-521.

33. Kahraman-Cetintas S, Turan-Ozdemir S, Topal U, Kurt M, Gokgoz S, et al (2008) Carcinoma originating from aberrant breast tissue. A case report and review of the literature. Tumori 94: 440-443.

34. Brooke RD, Blackwell K (2005) Ectopic breast cancer: rare, treatable, and potentially curable. Commun Oncol 2: 120-122. 